\title{
Effects of $\mathrm{NO}_{2}$ and Ozone on Pollen Allergenicity
}

\author{
Ulrike Frank* and Dieter Ernst \\ Institute of Biochemical Plant Pathology, Helmholtz Zentrum München - German Research Center for Environmental Health, \\ Neuherberg, Germany
}

This mini-review summarizes the available data of the air pollutants $\mathrm{NO}_{2}$ and ozone on allergenic pollen from different plant species, focusing on potentially allergenic components of the pollen, such as allergen content, protein release, IgE-binding, or protein modification. Various in vivo and in vitro studies on allergenic pollen are shown and discussed.

Keywords: pollen, allergens, $\mathrm{NO}_{2}$, ozone, air pollution

\section{INTRODUCTION}

Allergic diseases are increasing in Europe. The potential reasons discussed for this trend include climate change and anthropogenic air pollution (Kramer et al., 2000; Ring et al., 2001). It has been shown that ozone and $\mathrm{NO}_{2}$, which are two important air pollutants, can have an adverse effect on human health, e.g., the lung function, such as the initiation of lung inflammation by ozone (Kagawa, 1985; Uysal and Schapira, 2003). These air pollutants not only affect human health but also impact plants and their pollen. Ground level ozone, which is a secondary pollutant, is the result of a photochemical reaction of volatile organic compounds and nitrogen oxides $\left(\mathrm{NO}_{\mathrm{x}}\right)$, which are mainly produced by combustion processes during energy production, industrial processing or car traffic. Ozone again can also interact with $\mathrm{NO}_{\mathrm{x}}$. In rural areas, $\mathrm{NO}_{2}$ concentrations of up to $20 \mathrm{ppb}$ can be measured, whereas in urban traffic regions, values up to $90 \mathrm{ppb}$ are detectable. In case of ozone, ozone levels along high traffic roads are often low, since ozone is depleted due to the high NO-concentration. At rural sites ozone concentrations often are higher, even so less precursors components are available, since polluted air is transported to the country sites and can react to ozone while the transport. The information threshold for ozone is 1-h average of $90 \mathrm{ppb}$, but on sunny days alert threshold level of $120 \mathrm{ppb}$ 1-h average can be reached (www.eea.europa.eu).

Air pollution can impact pollen morphology, the pollen cell wall, the pollen protein content or protein release from the pollen as well as the pollen protein itself. In addition, the pollen coat, which is a complex mixture of pigments, waxes, lipids, aromatics and proteins (Edlund et al., 2004), might be impaired due to air pollution. Regarding pollen allergenicity, not only allergenic proteins do play a role, but pollen-derived lipids, which are also called pollen-derived lipid mediators (PALMs), also interact with the immune system and can modify the allergenic reaction (Traidl-Hoffmann et al., 2003; Bashir et al., 2013).

Received: 25 November 2015

Accepted: 18 January 2016

Published: 04 February 2016

\section{THE IMPACT OF OZONE ON POLLEN ALLERGENICITY}

Concerning the effect of traffic-/industrial-related air pollution on allergenic pollen, most studies have been interested in the allergens, including the allergen content, the possibility of allergen/protein release from the pollen or possible modifications to the allergens. Interestingly, 
approximately one-fourth of known plant allergens are pathogenrelated proteins (PR-proteins), which are induced by different biotic and abiotic stresses, including ground-level ozone (Sandermann et al., 1998; Hoffmann-Sommergruber, 2002). One example is Bet v 1, the major allergen from birch (Betula pendula), which is a PR-10 protein. Beck et al. (2013) showed that the Bet v 1 allergen content is positively correlated with increasing ozone levels. This in vivo study also indicated significantly larger wheal and flare sizes in patients pricked with pollen extracts from high ozone stands, which was consistent with the higher Bet v 1 content in the pollen (Beck et al., 2013). Another PR protein known as an allergen is the thaumatin-like protein Cup a 3 from Cupressus arizonica, which was shown to increase under polluted air conditions (Cortegano et al., 2004; Suárez-Cervera et al., 2008). A further study on another tree species, Pinus radita, showed greater allergenicity in terms of prick test and specific IgE binding in connection with higher ozone levels in unpolluted areas (García-Gallardo et al., 2013). The sensitivity to ozone seems to be both species- and concentration-dependent. In an in vitro study with ozone concentrations of half, equal and four times the standard limit according to the European Union Directive 2008/50/EC on ambient air quality, the pollen of Acer negundo, Platanus ssp. and Quercus robur showed differences in the total soluble protein (TSP) content. Whereas Q. robur and Platanus ssp. exhibited significantly reduced protein content under all treatments, $A$. negundo only showed a decrease when it was fumigated with the highest ozone concentration (Ribeiro et al., 2013). Concerning the specific IgE reactivity to Q. robur and $A$. negundo pollen extracts, the majority of the tested sera showed increased or unchanged IgE activity compared to the control, but for Platanus ssp., the untreated samples showed the highest IgE binding (Ribeiro et al., 2014). Increased allergen contents due to elevated ozone have also been shown for other plant species, such as Lollium perenne and Secale cereale (Masuch et al., 1997; Eckl-Dorna et al., 2010). A study on grass pollen (Phleum pratense) fumigated in vitro with $100 \mathrm{ppb}$ ozone for 4 hours resulted in the acidification of several allergens ( $\mathrm{Phl} p$ $1 \mathrm{~b}, 4,5$, and 6) as well as decreased $\operatorname{IgE}$ recognition of the allergens Phl p 1, 2, 6, and 13 in immunoblots, as explained by the mechanical loss of allergens from altered pollen grains (Rogerieux et al., 2007; Table 1). The exposure of Phleum pratense pollen to increasing ozone-concentrations from $100 \mathrm{ppb}$ up to $5 \mathrm{ppm}$ resulted in a significant increase in the naturally released pollen cytoplasmic granules (PCG), which are also known to contain allergens, and in more damage to the pollen grain. This mechanism of allergen release might explain the increase in thunderstorm asthma (Motta et al., 2006). Two other studies on in vivo and in vitro fumigated ragweed pollen did not find any differences in the allergen content of the major allergen Amb a 1 (Pasqualini et al., 2011; Kanter et al., 2013), but differences in the pollen cell wall and increased NADPH oxidase activity could be detected. NADPH oxidase activity was already shown to influence allergenic reactions due to the release of reactive oxygen species (Bacsi et al., 2005). In addition, cell wall modifications might affect immune reaction: in ozone-fumigated ragweed pollen, reduced levels of wax compounds have been detected, and high ozone levels resulted in an altered lipid composition of birch pollen, which led to a modulated immune response (Beck et al., 2013; Kanter et al., 2013).

\section{$\mathrm{NO}_{2}$ IS IMPACTING THE POLLEN ALLERGENICITY}

Several studies have been performed examining the influence of $\mathrm{NO}_{2}$ on pollen allergenicity. Three in vitro studies exposing

TABLE 1 | Studies of the effect of $\mathrm{NO}_{2}$ and/or ozone on the allergenic potential of different pollen species.

\begin{tabular}{|c|c|c|c|c|c|c|}
\hline Species & Pollutant & Concentration & Exposure time & Allergen & IgE binding & Reference \\
\hline \multirow[t]{2}{*}{ Acer negundo } & $\mathrm{O}_{3}$ & 30-235 ppb & $6 \mathrm{~h}$ & & $\uparrow$ & Ribeiro et al., 2014 \\
\hline & $\mathrm{NO}_{2}$ & 150-300 ppb & $6 \mathrm{~h}$ & & $\uparrow$ & Sousa et al., 2012 \\
\hline \multirow[t]{4}{*}{ Ambrosia artemisiifolia } & $\mathrm{O}_{3}$ & 80 ppb & Growing season & Amb a $1=$ & & Kanter et al., 2013 \\
\hline & $\mathrm{O}_{3}$ & 100 ppb & 7 day & Amb a $1=$ & & Pasqualini et al., 2011 \\
\hline & $\mathrm{NO}_{2}$ & 80 ppb & Growing season & Amb a $1 \uparrow$ & $\uparrow$ & Zhao et al., 2015 \\
\hline & $\mathrm{NO}_{2}$ & High traffic roads & & & $\uparrow$ & Ghiani et al., 2012 \\
\hline Betula ssp. & $\mathrm{O}_{3}$ & Outside stands & & Bet $\vee 1 \uparrow$ & & Beck et al., 2013 \\
\hline Betula pendula & $\mathrm{NO}_{2}$ & 34/67 ppb & $6 / 48 h$ & & $\uparrow$ & Cuinica et al., 2014 \\
\hline Carpinus betulus & $\mathrm{NO}_{2}$ & $34 / 67 \mathrm{ppb}$ & $6 / 48 h$ & & $\uparrow$ & Cuinica et al., 2014 \\
\hline Lolium perenne & $\mathrm{O}_{3}$ & $\begin{array}{l}65 \text { ppb } \\
\text { outside stands }\end{array}$ & $\begin{array}{l}2 \text { weeks } \\
-\end{array}$ & $\begin{array}{l}\text { Phl p } 5 \uparrow \\
\text { Phl p } 5 \uparrow\end{array}$ & & Masuch et al., 1997 \\
\hline Phleum pratense & $\begin{array}{l}\mathrm{O}_{3} \\
\mathrm{NO}_{2} \\
\mathrm{O}_{3} / \mathrm{NO}_{2}\end{array}$ & $\begin{array}{l}100 \text { ppb } \\
2000 \text { ppb } \\
100 \text { ppb/2000 ppb }\end{array}$ & $4 \mathrm{~h}$ & & $\begin{array}{l}\downarrow \\
\downarrow \\
\downarrow\end{array}$ & Rogerieux et al., 2007 \\
\hline Pinus radita & $\mathrm{O}_{3}$ & Outside stands & & & $\uparrow$ & García-Gallardo et al., 2013 \\
\hline Secale cereale & $\mathrm{O}_{3}$ & 80 ppb & 107 days & $\begin{array}{l}\text { Phl p } 1 \uparrow \\
\text { Phl p } 5 \uparrow \\
\text { Phl p } 6 \uparrow \\
\text { Profilin } \uparrow\end{array}$ & & Eckl-Dorna et al., 2010 \\
\hline
\end{tabular}

$\uparrow=$ increased; $\downarrow=$ reduced. 
grass pollen ( $P$. pratense) to artificially high $\mathrm{NO}_{2}$-concentrations from $500 \mathrm{ppb}$ up to $5000 \mathrm{ppm}$ resulted in a dose-dependent increase in PCGs and a dose-dependent increase in pollen grain damage (Motta et al., 2006) as well as a reduction of IgE binding to Phl p 2, 5b, and 6 (Rogerieux et al., 2007). In addition, a direct correlation of $\mathrm{NO}_{2}$ uptake by the pollen with a higher $\mathrm{T}_{\mathrm{H}} 2$ response of human cells could be demonstrated (Chassard et al., 2015), which indicated that $\mathrm{NO}_{2}$ can interact with the pollen grains and thus leads to degradation of pollen structure and changes in protein content. Other studies on ragweed (Ambrosia artemisiifolia) showed higher allergen levels and elevated IgE binding under elevated $\mathrm{NO}_{2}$ concentrations, where the higher IgE recognition was mainly due to the major allergen Amb a 1 (Ghiani et al., 2012; Zhao et al., 2015). Zhao et al. (2015) also showed IgE binding to a new allergen in ragweed with homology to $\mathrm{Hev}$ b 9 from the rubber tree, induced by elevated $\mathrm{NO}_{2}$ (Zhao et al., 2015). However, contrary results were found for several tree pollen species fumigated with $\mathrm{NO}_{2}$ concentrations between 34 and 300 ppb. Betula pendula and Carpinus betulus showed decreased pollen viability when exposed to $\mathrm{NO}_{2}$ and had a lower TSP content. Ostrya carpinifolia also showed a lower TSP compared with the control. This study also demonstrated increased pollen allergenicity for C. betulus, O. carpinifolia, and B. pendula when exposed for a short time to relatively small $\mathrm{NO}_{2}$ concentrations (Cuinica et al., 2014). A. negundo also showed similarly elevated IgE binding but slightly increased TSP, whereas lower TSP was detected for Ricinus communis (Bist et al., 2004; Sousa et al., 2012).

Air pollution due to $\mathrm{NO}_{2}$ can result in post-translational modification such as S-nitrosylation or the nitration of pollen proteins. Zhao et al. (2015) showed that the fumigation of ragweed plants with elevated $\mathrm{NO}_{2}$ concentrations throughout a growing season resulted in increased overall S-nitrosylation,

\section{REFERENCES}

Ackaert, C., Kofler, S., Horejs-Hoeck, J., Zulehner, N., Asam, C., von Grafenstein, S., et al. (2014). The impact of nitration on the structure and immunogenicity of the major birch pollen allergen Bet v 1.0101. PLoS ONE 9:e104520. doi: 10.1371/journal.pone.0104520

Bacsi, A., Dharajiya, N., Choudhury, B. K., Sur, S., and Boldogh, I. (2005). Effect of pollen-mediated oxidative stress on immediate hypersensitivity reactions and late-phase inflammation in allergic conjunctivitis. J. Allergy Clin. Immunol. 116, 836-843. doi: 10.1016/j.jaci.2005.06.002

Bashir, M. E. H., Lui, J. H., Palnivelu, R., Naclerio, R. M., and Preuss, D. (2013). Pollen lipidomics: lipid profiling exposes a notable diversity in 22 allergenic pollen and potential biomarkers of the allergic immune response. PLOS ONE 8:e57566. doi: 10.1371/journal.pone.0057566

Beck, I., Jochner, S., Gilles, S., McIntyre, M., Buters, J. T. M., Schmidt-Weber, C., et al. (2013). High environmental ozone levels lead to enhanced allergenicity of birch pollen. PLoS ONE 8:e80147. doi: 10.1371/journal.pone.0080147

Bist, A., Pandit, T., Bhatnagar, A. K., and Singh, A. B. (2004). Variability in protein content of pollen of Castor bean (Ricinus communis) before and after exposure to the air pollutants $\mathrm{SO}_{2}$ and $\mathrm{NO}_{2}$. Grana 43, 94-100. doi: 10.1080/00173130410019316

Chassard, G., Choël, M., Gosselin, S., Vorng, H., Petitprez, D., Shahali, Y., et al. (2015). Kinetic of NO2 uptake by Phleum pratense pollen: chemical and allergenic implications. Environmental Pollution 196, 107-113. doi: 10.1016/j.envpol.2014.10.004

Cortegano, I., Civantos, E., Aceituno, E., Del Moral, A., López, E., Lombardero, M., et al. (2004). Cloning and expression of a major allergen from Cupressus and LC-MS/MS analysis of the S-nitrosylated proteins indicated the major ragweed allergen Amb a 1 as a possible candidate for S-nitrosylation (Zhao et al., 2015). Another important aspect is the nitration of allergens in pollen, which can be caused by the presence of ozone and $\mathrm{NO}_{2}$. Studies on aerosolized proteins showed an ozone dependent increase of nitration due to $\mathrm{NO}_{2}$ (Shiraiwa et al., 2012). Franze et al. (2005) showed that the major allergen from birch Bet $\mathrm{v} 1$ is effectively nitrated in the presence of $\mathrm{NO}_{2}$ and ozone but that the nitration degree was substantially lower when the proteins were exposed to $\mathrm{NO}_{2}$ alone, thus indicating that reactive species formed upon the interaction of ozone and $\mathrm{NO}_{2}$ play a major role in the nitration. This nitration affects the allergenic potential of the birch pollen. The nitration of Bet v1 results in stronger proliferation of Bet $\mathrm{v} 1$-specific $\mathrm{T}$ cell lines, and $\operatorname{IgE}$ binding to nitrated Bet $\mathrm{v} 1$ is higher than $\operatorname{IgE}$ binding to Bet v 1 (Gruijthuijsen et al., 2006; Karle et al., 2012). An oligomerization of Bet v 1 due to nitration was also observed, which resulted in lower sensitivity to endolysomal degradation (Ackaert et al., 2014). This posttranslational modification of allergens provides a rationale for the increase in allergic diseases in air polluted regions.

Summarizing the different studies, little is yet known about the molecular mechanisms of the effects of ozone and $\mathrm{NO}_{2}$ on pollen, and more research is needed on that point. However, the existing research already clearly indicates dose-dependent and speciesspecific impacts of these air pollutants, which in most cases result in heightened allergenicity.

\section{AUTHOR CONTRIBUTIONS}

UF and DE contributed equally to the manuscript concerning writing and conception.

arizonica pollen, Cup a 3, a PR-5 protein expressed under polluted environment. Allergy 59, 485-490. doi: 10.1046/j.1398-9995.2003. 00363.x

Cuinica, L. G., Abreu, I., and da Silva, J. (2014). Effect of air pollutant NO2 on Betula pendula, Ostrya carpinifolia and Carpinus betulus pollen fertility and human allergenicity. Environ. Pollut. 186, 50-55. doi: 10.1016/j.envpol.2013.12.001

Eckl-Dorna, J., Klein, B., Reichenauer, T. G., Niederberger, V., and Valenta, R. (2010). Exposure of rye (Secale cereale) to elevated ozone levels increases the allergen content in pollen. J. Allergy Clin. Immunol. 126, 1315-1317. doi: 10.1016/j.jaci.2010.06.012

Edlund, A. F., Swanson, R., and Preuss, D. (2004). Pollen and stigma structure and function: the role of diversity in pollination. Plant Cell 16, S84-S97. doi: 10.1105/tpc.015800

Franze, T., Weller, M. G., Niessner, R., and Pöschl, U. (2005). Protein nitration by polluted air. Environ. Sci. Technol. 39, 1673-1678. doi: 10.1021/es0488737

García-Gallardo, M. V., Algorta, J., Longo, N., Espinel, S., Aragones, A., Lombardero, M., et al. (2013). Evaluation of the effect of pollution and fungal disease on Pinus radiata pollen allergenicity. Int. Arch. Allergy Immunol. 160, 241-250. doi: 10.1159/000341368

Ghiani, A., Aina, R., Asero, R., Bellotto, E., and Citterio, S. (2012). Ragweed pollen collected along high-traffic roads shows a higher allergenicity than pollen sampled in vegetated areas. Allergy 67, 887-894. doi: 10.1111/j.13989995.2012.02846.X

Gruijthuijsen, Y. K., Grieshuber, I., Stocklinger, A., Tischler, U., Fehrenbach, T., Weller, M. G., et al. (2006). Nitration enhances the allergenic potential of proteins. Int. Arch. Allergy Immunol. 141, 265-275. doi: 10.1159/000095296 
Hoffmann-Sommergruber, K. (2002). Pathogenesis-related (PR)-proteins identified as allergens. Biochem. Soc. Trans. 30, 930-935. doi: 10.1042/bst 0300930

Kagawa, J. (1985). Evaluation of biological significance of nitrogen oxides exposure. Tokai J. Exp. Clin. Med. 10:348.

Kanter, U., Heller, W., Durner, J., Winkler, J. B., Engel, M., Behrendt, H., et al. (2013). Molecular and immunological characterization of ragweed (Ambrosia artemisiffolia L.) pollen after exposure of the plants to elevated ozone over a whole growing season. PLoS ONE 8:e61518. doi: 10.1371/journal.pone.0061518

Karle, A. C., Oostingh, G. J., Mutschlechner, S., Ferreira, F., Lackner, P., Bohle, B., et al. (2012). Nitration of the pollen allergen Bet v 1.0101 enhances the presentation of Bet $\mathrm{v}$ 1-derived peptides by HLA-DR on human dendritic cells. PLoS ONE 7:e31483. doi: 10.1371/journal.pone.0031483

Kramer, U., Koch, T., Ranft, U., Ring, J., and Behrendt, H. (2000). Traffic-related air pollution is associated with atopy in children living in urban areas. Epidemiology 11, 64-70. doi: 10.1097/00001648-200001000-00014

Masuch, G., Franz, J. T., Schoene, K., Müsken, H., and Bergmann, K. C. (1997). Ozone increases group 5 allergen content of Lolium perenne. Allergy 52, 874-875. doi: 10.1111/j.1398-9995.1997.tb02163.x

Motta, A. C., Marliere, M., Peltre, G., Sterenberg, P. A., and Lacroix, G. (2006). Traffic-related air pollutants induce the release of allergen-containing cytoplasmic granules from grass pollen. Int. Arch. Allergy Immunol. 139, 294298. doi: $10.1159 / 000091600$

Pasqualini, S., Tedeschini, E., Frenguelli, G., Wopfner, N., Ferreira, F., D’Amato, G., et al. (2011). Ozone affects pollen viability and $\mathrm{NAD}(\mathrm{P}) \mathrm{H}$ oxidase release from Ambrosia artemisiifolia pollen. Environ. Pollut. 159, 2823-2830. doi: 10.1016/j.envpol.2011.05.003

Ribeiro, H., Duque, L., Sousa, R., and Abreu, I. (2013). Ozone effects on soluble protein content of Acer negundo, Quercus robur and Platanus spp. pollen. Aerobiologia 29, 443-447. doi: 10.1007/s10453-013-9291-5

Ribeiro, H., Duque, L., Sousa, R., Cruz, A., Gomes, C., da Silva, J., et al. (2014). Changes in the IgE-reacting protein profiles of Acer negundo, Platanus $\mathrm{x}$ acerifolia and Quercus robur pollen in response to ozone treatment. Int. J. Environ. Health Res. 24, 515-527. doi: 10.1080/09603123.2013.865716

Ring, J., Krämer, U., Schäfer, T., and Behrendt, H. (2001). Why are allergies increasing? Curr. Opin. Immunol. 13, 701-708. doi: 10.1016/S09527915(01)00282-5

Rogerieux, F., Godfrin, D., Sénéchal, H., Motta, A. C., Marlière, M., Peltre, G., et al. (2007). Modifications of Phleum pratense grass pollen allergens following artificial exposure to gaseous air pollutants $\left(\mathrm{O}_{3}, \mathrm{NO}_{2}, \mathrm{SO}_{2}\right)$. Int. Arch. Allergy Immunol. 143, 127-134. doi: 10.1159/000099079

Sandermann, H. Jr., Ernst, D., Heller, W., and Langebartels, C. (1998). Ozone: an abiotic elicitor of plant defence reactions. Trends Plant Sci. 3, 47-50. doi: 10.1016/s1360-1385(97)01162-x

Shiraiwa, M., Selzle, K., Yang, H., Sosedova, Y., Ammann, M., and Pöschl, U. (2012). Multiphase chemical kinetics of the nitration of aerosolized protein by ozone and nitrogen dioxide. Environ. Sci. Technol. 46, 6672-6680. doi: 10.1021/es300871b

Sousa, R., Duque, L., Duarte, A. J., Gomes, C. R., Ribeiro, H., Cruz, A., et al. (2012). In vitro exposure of Acer negundo pollen to atmospheric levels of $\mathrm{SO} 2$ and $\mathrm{NO}_{2}$ : effects on allergenicity and germination. Environ. Sci. Technol. 46, 2406-2412. doi: 10.1021/es2034685

Suárez-Cervera, M., Castells, T., Vega-Maray, A., Civantos, E., del Pozo, V., Fernández-González, D., et al. (2008). Effects of air pollution on Cup a 3 allergen in Cupressus arizonica pollen grains. Ann. Allergy Asthma Immunol. 101, 57-66. doi: 10.1016/S1081-1206(10)60836-8

Traidl-Hoffmann, C., Kasche, A., Menzel, A., Jakob, T., Thiel, M., Ring, J., et al. (2003). Impact of pollen on human health: more than allergen carriers? Int. Arch. Allergy Immunol. 131, 1-13. doi: 10.1159/0000 70428

Uysal, N., and Schapira, R. M. (2003). Effects of ozone on lung function and lung diseases. Curr. Opin. Pulm. Med. 9, 144-150. doi: 10.1097/00063198200303000-00009

Zhao, F., Elkelish, A., Durner, J., Lindermayr, C., Winkler, J. B., Ruëff, F., et al. (2015). Common ragweed (Ambrosia artemisiifolia L.): allergenicity and molecular characterisation of pollen after plant exposure to elevated $\mathrm{NO}_{2}$. Plant Cell Environ. 39, 147-164. doi: 10.1111/pce.12601

Conflict of Interest Statement: The authors declare that the research was conducted in the absence of any commercial or financial relationships that could be construed as a potential conflict of interest.

Copyright (c) 2016 Frank and Ernst. This is an open-access article distributed under the terms of the Creative Commons Attribution License (CC BY). The use, distribution or reproduction in other forums is permitted, provided the original author(s) or licensor are credited and that the original publication in this journal is cited, in accordance with accepted academic practice. No use, distribution or reproduction is permitted which does not comply with these terms. 